\title{
EDUKASI PENYAKIT DIABETES MELLITUS TIPE-2 DAN PENERAPAN TATA LAKSANA DIET UNTUK MENGENDALIKAN GLUKOSA DARAH
}

\author{
Reno Irwanto ${ }^{1 *}$, Raini Panjaitan ${ }^{1}$, Annisa Febriana Siregar ${ }^{1}$, Anggi Isnani \\ Parinduri $^{1}$ \\ ${ }^{1}$ Program Studi Gizi, Institut Kesehatan Medistra Lubuk Pakam \\ Jl. Sudirman No.38 Petapahan, Lubuk Pakam, Kabupaten Deli Serdang, \\ Sumatera Utara - Indonesia 20512 \\ *email korespondensi author: ireno@outlook.com \\ DOI $10.35451 / j p k . v 1 \mathrm{i} 1.736$
}

\begin{abstract}
Abstrak
Penyakit tidak menular seperti Diabetes mellitus (DM) menunjukkan kenaikan setiap tahunnya. Hal ini dikarenakan penyakit DM merupakan penyakit yang belum diketahui cara penyembuhannya selain melakukan pencakokan pankreas sebagai produsen insulin. DM dapat berakibat fatal bila tidak dikelola dengan baik dan dapat menyebabkan komplikasi penyakit lainnya. DM terdiri atas 3 tipe yaitu, DM Tipe1 (DMT1), DM Tipe2 (DMT2), dan DM Tipe3 (gestational). DMT2 adalah kondisi tubuh dengan jumlah produksi insulin yang kurang ataupun insulin tidak bekerja dengan optimal sehingga terjadi hiperglikemia. Terjadinya penyakit DMT2 dapat disebabkan oleh buruknya pola makan, gaya hidup dan kurangnya aktifitas fisik. Dalam usaha mencegah dan mengendalikan hal tesebut diperlukan suatu usaha. Edukasi penerapan tata laksana diet merupakan salah satu cara yang dapat dilakukan untuk mengendalikan glukosa darah pasien DMT2 serta mencegah terjadinya peningkatan keparahan penyakit dan komplikasi. Pasien yang mengikuti edukasi penyakit DMT2 yang dilaksanakan di RS Grandmed Lubuk Pakam berjumlah 50 orang dengan persentase laki-laki $56,7 \%$ dan perempuan 43,3\% kemudian nilai pengukuran tekanan darah peserta yang normal 97,3\% dan hipertensi 2,7\%. Edukasi merupakan salah satu cara yang direkomenasikan oleh WHO dalam menekan terjadinya peningkatan dan keparahan penyakit DMT2. Hasil edukasi yang telah dilakukan diharapkan dapat meningkatkan kewaspadaan dan perhatian peserta dalam mengedalikan penyakit DMT2 melalui penerapan tata laksana diet yang telah diberikan.
\end{abstract}

Kata Kunci: Diabetes mellitus, Edukasi, glukosa darah

\begin{abstract}
Non-communicable diseases such as Diabetes mellitus (DM) show an increase every year. This is because DM is a disease that has no known cure other than transplanting the pancreas as insulin producer. DM can be fatal if not managed properly and can cause complications of other diseases. DM consists of 3 types, namely, DM Type 1 (DMT1), DM Type 2 (DMT2), and DM Type 3 (gestational). DMT2 is a condition in which the body produces insufficient insulin or insulin does not work optimally, resulting in hyperglycemia. The occurrence of DMT2 disease can be caused by poor diet, lifestyle and lack of physical activity. In an effort to prevent and control this, an effort is needed. Education on the application of dietary management is one way that can be done to control blood glucose in
\end{abstract}


T2DM patients and prevent an increase in disease severity and complications. There were 50 patients who attended DMT2 disease education at Grandmed Lubuk Pakam Hospital with the percentage of men $56.7 \%$ and women $43.3 \%$ then the measurement value of normal participants' blood pressure was $97.3 \%$ and hypertension $2.7 \%$. Education is one of the ways recommended by WHO in suppressing the increase and severity of DMT2 disease. The results of the education that have been carried out are expected to increase the awareness and attention of participants in controlling DMT2 disease through the application of the diet management that has been given.

Keyword : Diabetes mellitus, public education, blood glucose

\section{Pendahuluan}

Diabetes mellitus (DM) merupakan penyakit kronik yang terjadi akibat pankreas tidak mampu menghasilkan insulin atau ketika tubuh tidak mampu memanfaatkan insulin. Insulin merupakan komponen penting yang dibutuhkan tubuh dalam perubahan glukosa menjadi energi. Insulin dihasilkan oleh pankreas yang merupakan golongan hormon. Ketiadaan atau kurangnya kemampuan kerja insulin akan menyebabkan terjadinya penumpukan glukosa didalam darah. Peningkatan glukosa darah akan dapat menyebabkan kondisi hiperglikemia. Dalam waktu Panjang, ketiadaan insulin akan dapat menimbulkan komplikasi yang memiliki risiko pada kerusakan organ dan jaringan sehingga timbul penyakit lainnya (IDF, 2019).

DM merupakan penyakit yang berhubungan dengan fungsi dan keberadaan hormon insulin. Berdasarkan hal tersebut, diabetes mellitus dibagi atas beberapa tipe. DM tipe 1 , tipe 2 dan gestasional (IDF 2017). DM tipe 1 terjadi ketika pankreas menghasilkan insulin dalam jumlah kecil atau bahkan tidak dapat menghasilkan hormon insulin. DM tipe 2 terjadi ketika pankreas tidak mampu memanfaatkan hormon insulin dengan baik. Hal tersebut terjadi dapat disebabkan oleh buruknya pola makan, gaya hidup. DM gestasional terjadi pada ibu hamil dengan usia $>45$ tahun. Hal tersebut terjadi karena adanya perubahan antara janin dan ibu tersebut.

Irwanto (2021), terdapat hubungan terjadinya penyakit DM tipe-2 dengan buruknya pola makan, kurangnya aktifitas fisik. Menurut IDF (2017), asupan karbohidrat, lemak, dan protein memiiki pengaruh yang signifikan dalam status gizi dan tingkat keparah penyakit DM tipe-2.

Menurut kaban (2007) dalam ardiansah et al. (2012) penyakit diabetes merupakan penyakit yang jumlahnya akan semakin meningkat. Hal ini karena penderita DM Tipe-2 akan seumur hidup mengalami mengalami hiperglikemia akibat gangguan kerusakan pankreas. Dengan demikian apabila penderita DM tipe-2 tidak sembuh maka dari tahun ke tahun jumlahnya akan semakin meningkat.

Menurut IDF (2019), jumlah penderita DM meningkat sebesar 15\% secara global. Kawasan Asia Tenggara menduduki posisi ketiga sebagai kawasan dengan tingkat pertumbuhan terbesar akan penderita diabetes yaitu sebesar 74\%. Pada tahun 2019 indonesia menempati 7 dalam jumlah penderita sebesar 10.7 juta orang dan akan terus meningkat pada tahun 2045 dengan jumlah angka penderita diperkirakan sebesar 16.6 juta penderita.

Menurut Sundari (2016) dalam Muliasari et al. (2019) kerusakan pankreas bersifat permanen sehingga akan menganggu produksi insulin. Hal ini 
Received: 10 June 2021 :: Accepted: 17 June 2021 :: Published: 30 June 2021

dapat menyebabkan penderita DM tipe-2 ketergantungan obat anti hiperglikemia bahkan input insulin dari luar. Pengelolaan dan tata laksana diet yang tepat merupakan salah satu cara yang dapat dilakukan dalam mengontrol glukosa darah.

Diperlukan peningkatan kualitas hidup penderita DM tipe-2 untuk mencegah terjadinya peningkatan keparahan penyakit dan komplikasi. Terdapat empat pilar utama yang diketahui dalam mencegah hal tersebut yaitu; edukasi, terapi nutrisi, aktifitas fisik, dan farmakologi. Dalam hal ini, adanya pengetahuan akan DM sangat penting perannya begitupun dengan 3 pilar lainnya. Edukasi penderita DM tipe-2 akan dapat meningkatkan kewaspadaan dan menghindari terjadinya risiko parah yang mungkin dapat terjadi. Pemberian edukasi dalam tata laksana diet atau terapi nutrisi memberikan pengetahuan dua pilar langsung kepada penderita yang diharapkan dapat menekan angka keparah penyakit DM tipe-2 (Putra et al. 2015)

\section{Metode}

Metode pelaksanaaan kegiatan pengabdian adalah sebagai berikut:

1. Pemeriksaan antropometri, glukosa darah sewaktu dan tekanan darah secara gratis

2. Edukasi tentang DM, risiko penyakit DM, cara pengendalian DM melalui penata laksanaan diet

3. Diskusi dan tanya jawab terkait DM, peningkatan kualitas hidup bagi penderita DM dan tata laksana diet.

Edukasi dalam peningkatan

penerapan tata laksana diet bagi penderita DM ini dilakukan bersama dosen dan mahasiswa Program Studi Gizi Fakultas Kesehatan Masyarakat Institut Kesehatan Medistra Lubuk Pakam yang bertempat di RS Granmed Lubuk Pakam. Sasaran kegiatan adalah para pasien RS Grandmed Lubuk Pakam yang berlokasi di
Jalan Raya Medan KM 25, No 66, Perdamaian, Lubuk Pakam, Kabupaten Deli Serdang, Sumatera Utara 20514. Digunakan cara edukasi dalam pendekatan berupa penyampaian materi dan diskusi tentang DM, risiko, pengendalian dan peningkatan kualitas hidup penderita DM.

\section{Hasil dan Pembahasan}

Edukasi terkait penyakit DM tipe-2 yang telah dilaksanakan di RS Grandmed Lubuk Pakam diikuti oleh 50 orang peserta. Peserta yang hadir dalam kegiatan tersebut merupakan pasien dan pengunjung RS Grandmed. Peserta yang ikut dalam kegiatan ini adalah insidentil yang dilaksanakan di ruang pertemuan RS Grandmed. Distribusi kehadiran peserta edukasi penyakit DM berdasarkan jenis kelamin dapat dilihat pada gambar 1 berikut ini.

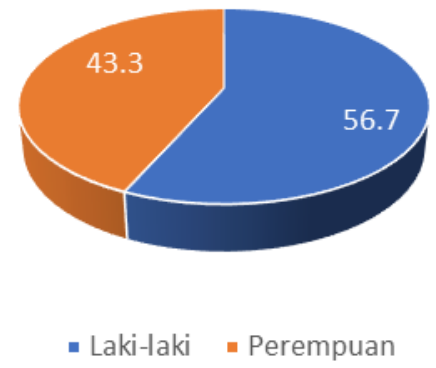

Gambar 1. Distribusi jenis kelamin peserta edukasi DM

Pelaksanaan edukasi dilakukan dengan meminta kesediaan para pasien dan pengunjung. Para peserta diminta untuk mengisi daftar hadir edukasi. Setelah dilakukan absensi, para peserta juga diberikan kesempatan untuk dilakukan pengukuran antropometri dan nilai glukosa darah sewaktu. Pengukuran antropometri dan glukosa darah untuk mengetahui profil tubuh dan nilai glukosa darah sewaktu yang dimiliki oleh peserta untuk diberikan pengarahan dan pemahaman. 
Received: 10 June 2021 :: Accepted: 17 June 2021 :: Published: 30 June 2021

\section{Selanjutnya para peserta} dipersilahkan untuk duduk dan diberikan makanan ringan sembari mengikuti acara edukasi. Kegiatan edukasi dimulai dengan pembukaan oleh kepala unit kerjasama publik dan penelitian RS Grandmed Lubuk Pakam. Berikutnya adalah edukasi terkait DM dan tata laksana diet untuk mengendalikan glukosa darah. Materi yang disampaikan saat edukasi adalah penyakit DM secara umum, tipe penyakit DM, tata laksana dan penerapan diet bagi penderita DM, serta motivasi untuk hidup sehat dan berkualitas sesuai arahan WHO. WHO menyatakan untuk hidup sehat ada 4 kuncinya yaitu; makan makanan sehat dan bergizi, aktifitas fisik, isirahat yang cukup dan selalu bahagia (tidak stress).

Nilai pengukuran tekanan darah peserta yang hadir saat edukasi dapat dilihat pada gambar 2 . Nilai tekanan darah peserta yang normal yaitu dikisaran 110$120 \mathrm{mmHg}$ adalah sebanyak 97,3\% sedangkan sisanya $2,7 \%$ nilai tekanan darahnya diatas angka normal yaitu $>130$ $\mathrm{mmHg}$.

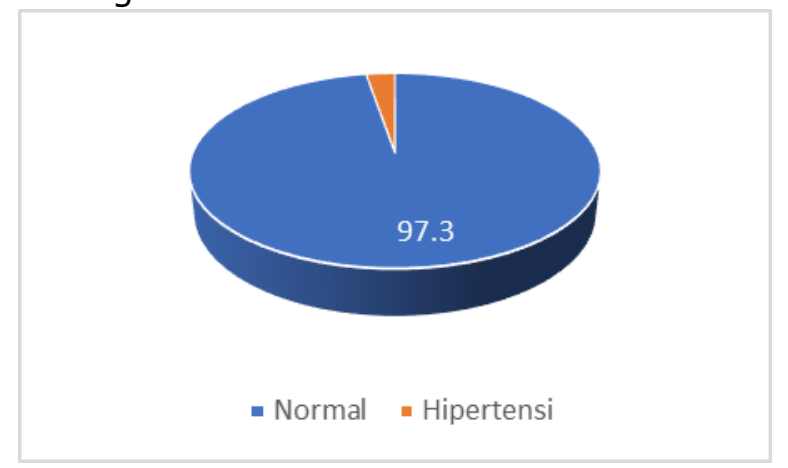

Gambar 2. Distribusi tekanan darah peserta edukasi DM

Peserta yang hadir dalam acara edukasi juga melakukan pengukuran antropometri berat badan. Dari pengukuran terlihat bahwa responden rata-rata memiliki berat badan normal. Berat badan secara tidak langsung juga memberikan risiko kenaikan angka potensi penyakit DM. pasien dengan berat badan tergolong kurang berat badannya tidak menutup kemungkinan terkena penyakit DM tipe-2. Dari hal tersebut narasumber juga menyampaikan bahwa DM merupakan penyakit yang tergolong silent killer. Oleh karena itu manajemen pengaturan diet pola makan akan sangat membantu dalam memberikan dan menjaga kualitas hidup yang baik.

Sebagai salah satu pilar untuk hidup sehat menurut WHO yaitu pengaturan pola makan. Pola makan yang sehat perlu untuk diterapkan terutama bagi penderita DM untuk menghindari terjadinya kenaikan glukosa darah secara ekstrim dan meningkatkan risiko penyakit komplikasi lainnya.

Edukasi yang telah diberikan terhadap peserta merupakan salah satu usaha dalam pengelolaan penyakit DM. WHO sendiri menyampaikan terdapat 4 cara pengelolaan DM bagi penderita yang terdiagnosa DM yaitu : edukasi, pengaturan pola makan, olahraga dan terapi pengobatan melalui farmakologi (Suyono 2015 dalam Muliasari 2019). Sebagai langkah awal penanggulangan peningkatan tingkat keparahan penyakit DM, edukasi merupakan salah satu usaha yang direkomendasikan dan diharapkan dapat menekan efek buruk dari DM dan memberikan kualitas hidup yang baik dengan pengelolaan diet.

\section{Kesimpulan}

Hasil edukasi dalam pengabdian kepada masyarakat yang dilaksanakan di RS Grandmed Lubuk Pakam diharapkan dapat meningkatkan kualitas hidup dan menekan angka komplikasi penyakit DM melalui pemahaman tata kelola diet yang telah diberikan.

\section{Ucapan Terima Kasih}

Ucapan terima kasih disampaikan kepada Lembaga Penelitian dan Pengabdian Masyarakat Institut Kesehatan Medistra Lubuk Pakam, Kepala Unit Kerjasama Pendidikan dan Penelitian 
Received: 10 June 2021 :: Accepted: 17 June 2021 :: Published: 30 June 2021

Rumah Sakit Grandmed Lubuk Pakam dan para Bapak/Ibu peserta edukasi.

\section{Daftar Pustaka}

Ardiansah N, Kharis M. 2012. Model matematika untuk penyakit diabetes tanpa faktor genetik. Jurnal Mipa: 35(1).

[IDF] International Diabetes Federation. 2017. IDF clinical practice recommendations for managing type 2 diabetes in primary care. Belgium.

[IDF] International Diabetes Federation. 2019. IDF Diabetes atlas. Ninth edition. Belgium.

Irwanto R, Siregar AF, Ginting KA, Ndruru F. 2021. faktor-faktor yang berhubungan dengan penyakit diabetes melitus tipe 2 pada pasien di rumah sakit grandmed lubuk pakam. Jurnal kesehatan masyarakat dan gizi: 3 (2).

Kaban S. 2007. Pengembangan Model Pengendalian Kejadian Penyakit Diabetes Mellitus Tipe 2 di Kota Sibolga. Majalah Kedokteran Nusantara 40(2): 119-128.

Muliasari $\mathrm{H}$, Hamdin $C D$, Ananto AD, Ihsan M. 2019. Edukasi dan deteksi dini diabetes mellitus sebagai upaya mengurangi prevalensi dan resiko penyakit degenerative. Jurnal pendidikan dan pengabdian masyarakat: 2 (1).

Putra IWA, Berani KN. 2015. Empat pilar penatalaksanaan pasien diabetes mellitus tipe 2. Majority: 4(9).

Sundari, S. 2016. Penyuluhan Tentang Penyakit Diabetes Mellitus Dan Osteoarthritis Di Dusun Kaliabu, Ambarketawang, Gamping, Sleman. Yogyakarta: Universitas Muhammadiah.

Suyono. 2015. Penatalaksanaan Diabetes mellitus terpadu sebagai panduan Penatalaksanaan Diabetes mellitus. Jakarta: FKUI. 